\title{
Valuation of Equity using Discounted Cash flow Method
}

\author{
D.O.I - 10.51201/Jusst12658 \\ http://doi.org/10.51201/Jusst12658 \\ Mrs.Shailaja Konek ${ }^{1}$ \\ Research Scholar, Gulbarga University, Kalaburagi \\ Ms.Srilakshmi.D ${ }^{2}$ \\ Research Scholar, VSK University,Bellary
}

\begin{abstract}
:
The growth of any economy depends on the strong financial system. Capital market plays a significant role in channelizing the savings into an investment activity by providing the platform to the investors as well as the firms to raise money. There are various instruments available for investment activities globally. Every investor has an objective to diversify portfolio globally to minimize risk among foreign markets and companies. Investor has to acquire the necessary skills to analyze the stocks to make better investment decisions in order to create wealth maximization. Valuation of equity is pre requisite for intelligent decision making in choosing the right scrip for investment in deciding the true value or intrinsic value of a share. There are few methodologies to evaluate the valuation of stocks such as discounted cash flow method, dividend discounted model. In this backdrop, this paper made an attempt to evaluate the Skyworks Solutions, Inc. stock with free cash flow to equity (FCFE) method of valuation during the 2016 to 2019 and to determine the intrinsic value of the stock and results found to be undervalued.
\end{abstract}

Key Words: Intrinsic Value, FCFE, Investment, portfolio

\section{INTRODUCTION:}

The most fundamental approach to value a firm is Discounted Cash Flow, which extends the present value principles that we developed to analyse projects to value a firm. The value of a firm is determined by four factors - its capacity to generate cash flows from assets in place, the expected growth rate of these cash flows, the length of time it will tale for the firm to reach stable growth and the cost of capital. We take the perspective of the investors in financial market 
in estimating value. Investors assess the value of a firm's stock in order to decide whether to buy or sell the stock.

One of the most significant inputs into any valuation is the expected growth rate in operating income. Although we could use past growth rate to make this estimate, the variable that drive expected growth are simple. The expected growth in the operating income is a product of a firm's reinvestment rate, that is, the proportion of after tax operating income that is invested in net capital expenditure and non-cash working capital and the quality of these reinvestments, measured as the return on the capital invested

\section{FREE CASH FLOW TO EQUITY MODEL}

In the free cash flow to equity approach, we estimate cash flows to equity investors in the firm and discount these cash flows at the cost of equity to arrive at the value of equity. Although the approach remains fundamentally the same as the firm valuation with following differences:

- Unlike the cash flow to the firm, which is after reinvestment needs but before debt payments, the cash flows to equity are cash flows after debt payments and new debt issued. When a constant proportion of reinvestment needs comes from debt, we can use the following equation.

- The discount rate is the cost of equity, rather than the cost of capital, since the cash flows are cash flows to equity investors.

- The expected growth rate is in equity earning (Net Income or Earning per Share) not operating income.

The value of the equity obtained from an equity valuation model by discounting cash flows to equity at the cost of equity ${ }^{1}$

\section{REVIEW LITERATURE}

Ms.Shradhanjali Panda (2013) ${ }^{2}$ examine the intrinsic value quarterly by discounted cash flow method (Equity free cash flow ) and compared to market value and tested by Welch's test to check significance level between the two values and robustness of the model by selecting five companies of different industries during from $1^{\text {st }}$ January $200131^{\text {st }}$ December 2010. Null 
hypothesis (There is no significant difference between the calculated value by using EFCF model and market value) is accepted in all cases except in Hereo Moto co.

Christoph Hukelmann et al...(2012) ${ }^{3}$ has tested the accuracy of equity valuation models such as discounted free cash flows, dividend discount model and abnormal earnings model for a three year forecast by calculating average, Median and Central tendency, correlation and multiple regression analysis were used for five specifications of 30 companies of DAX Index during 1990-2010. The study concluded that the dividend discount model and abnormal earnings have shown better accuracy than the free cashflow model.

Parakkal Nirmal Kumar (2018) ${ }^{4}$ assessment of intrinsic value of by Discounted cash flow method (free cash flow for the firm) of Maruti Suzuki India limited during 2018-2021. The methodology usedto examine the intrinsic value of stock by calculation of free cash flows, weighted average cost of capital, Growth rate by compounded annual growth rate for the last four years, Risk premium, Beta and Risk free rate of return. The study concluded that the intrinsic value of Maruti Suzuki was 6433.5, while the actual price of the stock was 7676 (as on 14-12-2018) implied that the stock was overvalued, hence suggested to sell the stock.

Ivanovska et al (2014) ${ }^{5}$ examined the valuation of stock market price prediction at Macedonian Stock Exchange by Discounted cash flow method of Granit SC, Skopje\& Vitaminka-Prilep SC during 2006-2010 and forecasting for six years. Fundamental analyses key financial ratio such as liquidity, leverage and profitability ratios were used to derive free cash flow for the company. Researcher concluded that the stock value calculated through Discounted cash flow method are very close to average market prices, hence DCF model are reliable technique for calculation of enterprise values in long term which is helpful for investors in predicting stock prices and make their better investment decisions.

\section{OBJECTIVES OF THE STUDY}

- To examine the intrinsic value of Skyworks Solutions, Inc through DCF approach.

- To recommend investor whether the stock is under-priced or over priced through the calculated intrinsic value. 


\section{RESEARCH METHODOLOGY:}

In this study, the researcher demonstrated the intrinsic value of the Skyworks Solutions, Inc. (SWKS) company and tried to provide signal to the investor to make decision based on the undervalued/overvalued concept. Data gathered in the study is completely secondary in nature and values are extracted from the period 2016 to 2019 to forecast the cash flows for further years.

Free Cash Flow to Equity Discount Model has been used for the calculation of cash flows to equity investors. The discount rate is the cost of equity, rather than the cost of capital, since the cash flows are cash flows to equity investors and it is calculated using CAPM model.

FCFE $=$ Net Income $-($ Capital Expenditure - Depreciation $)(1-$ Debt Ratio $)-$ Change in Noncash Working Capital (1 - Debt Ratio)

Growth rate is calculated by multiplying ROE with retention ratio to forecast the cash flow to future year from 2020 to 2023.

\section{DATA ANALYSIS AND INTERPRETATION}

Table No.1: Calculation of FCFE

\begin{tabular}{|c||c||c||c|c||c|c||}
\hline Year & $\begin{array}{c}\text { Net } \\
\text { Income }\end{array}$ & $\begin{array}{c}\text { Capital } \\
\text { Expenditure }\end{array}$ & Depreciation & $\begin{array}{c}\text { Debt } \\
\text { Ratio }\end{array}$ & $\begin{array}{c}\Delta \text { non cash } \\
\text { working capital }\end{array}$ & FCFE \\
\hline \hline 2016 & $9,95,200$ & $1,95,300$ & $2,47,800$ & 0.08 & $-1,99,900$ & $12,27,043.48$ \\
\hline \hline 2017 & $10,10,200$ & $3,15,400$ & $2,54,800$ & 0.11 & $1,41,100$ & $8,30,898.86$ \\
\hline 2018 & $9,18,400$ & $4,30,900$ & $2,99,200$ & 0.15 & $-79,500$ & $8,74,111.78$ \\
\hline 2019 & $8,53,600$ & $4,23,400$ & $3,71,600$ & 0.15 & 54,500 & $7,63,055.23$ \\
\hline \hline
\end{tabular}

Source: Computed by the author 
Figure 1: It shows the calculated year wise FCFE from the period 2016 to 2019

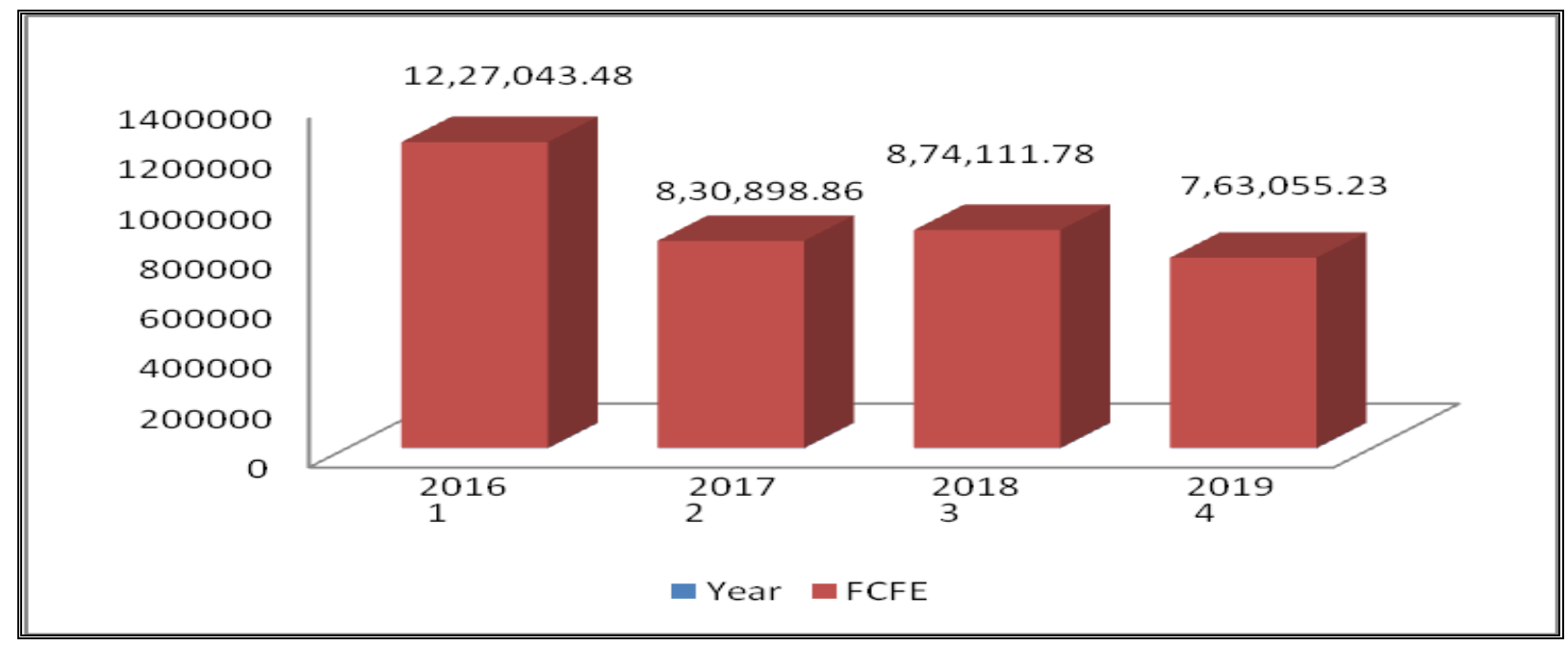

Table No.2: Calculation of Growth rate by using the formula i.e. product of retention ratio and return of equity.

\begin{tabular}{|c|c|c|c|c|}
\hline Year & Dividend Paid & $\begin{array}{c}\text { Retention } \\
\text { Rate=1-DPR }\end{array}$ & $\begin{array}{c}\text { Return On } \\
\text { Equity }\end{array}$ & Growth Rate \\
\hline 2016 & $2,01,000$ & $79.80 \%$ & $9.79 \%$ & $7.81 \%$ \\
\hline 2017 & $2,14,600$ & $78.76 \%$ & $10.88 \%$ & $8.57 \%$ \\
\hline 2018 & $2,43,200$ & $73.52 \%$ & $11.01 \%$ & $8.09 \%$ \\
\hline 2019 & $2,73,900$ & $67.91 \%$ & $10.54 \%$ & $7.16 \%$ \\
\hline \hline \multicolumn{3}{|c|}{ Average Growth Rate } & $\mathbf{7 . 9 1 \%}$ \\
\hline
\end{tabular}

Source: Computed by the author 
Figure 2: It shows the calculated year wise FCFE from the period 2016 to 2019 and average growth is considered for the further calculation.

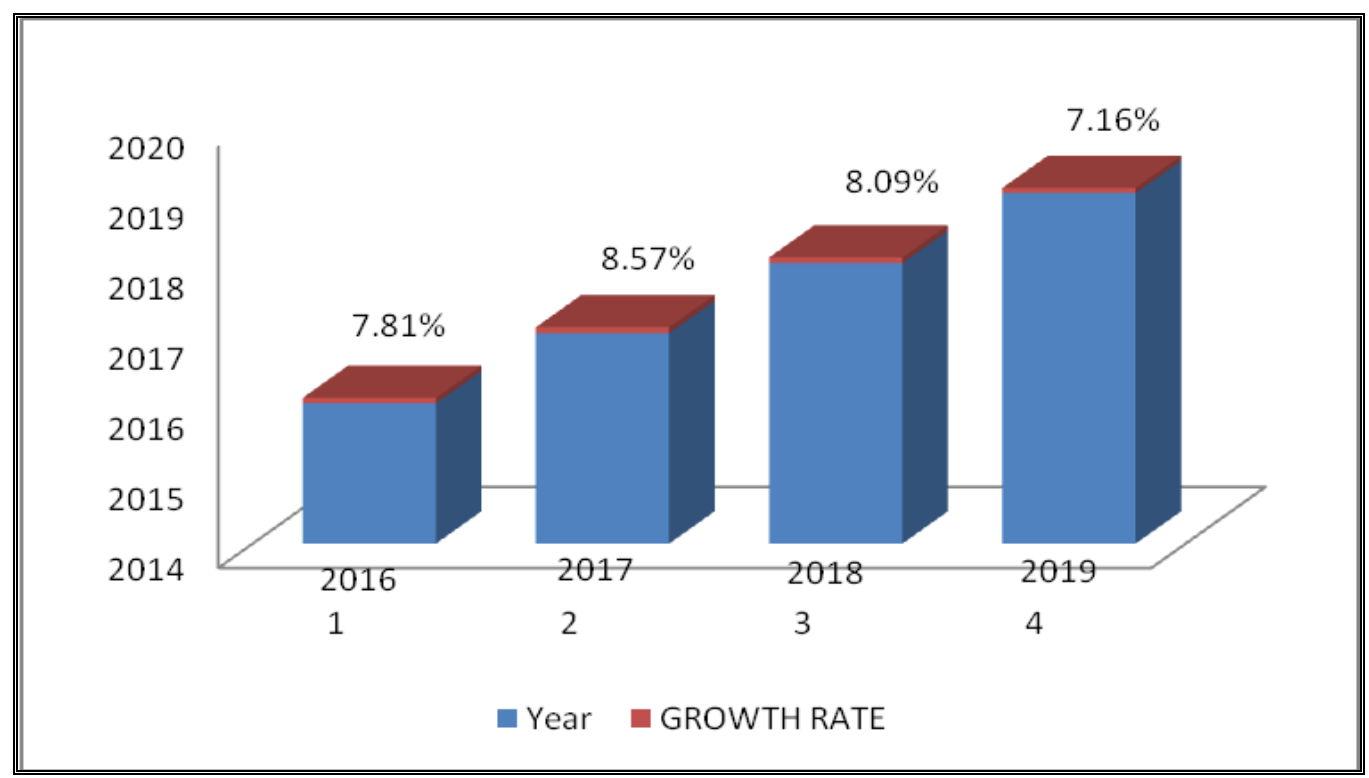

Table No.3: Claulcation of Cost of Equity

\begin{tabular}{|c|c|c|c|c|}
\hline Year & $\begin{array}{c}\text { Risk Free } \\
\text { Rate }\end{array}$ & $\begin{array}{c}\text { Market Risk } \\
\text { Premium }\end{array}$ & Beta* & $\begin{array}{c}\text { Cost Of } \\
\text { Equity }\end{array}$ \\
\hline \hline 2016 & $1.84 \%$ & $5.3 \%$ & 1.5 & $9.79 \%$ \\
\hline \hline 2017 & $2.33 \%$ & $5.7 \%$ & 1.5 & $10.88 \%$ \\
\hline 2018 & $2.91 \%$ & $5.4 \%$ & 1.5 & $11.01 \%$ \\
\hline 2019 & $2.14 \%$ & $5.6 \%$ & 1.5 & $10.54 \%$ \\
\hline \multicolumn{5}{|c|}{ Average Cost of Equity } \\
\hline
\end{tabular}

Source: Computed by the author

*Beta is assumed to be 1.5 for all the four years. 
Table No.4: Forecasting of equity cash flows from 2020 to 2023 and calculation Terminal Value(TV)

\begin{tabular}{|c|c|c|c|}
\hline Year & $\begin{array}{c}\text { FCF=Avg FCFE } \\
\text { Avg Growth rate }\end{array}$ & $\begin{array}{c}\text { Discount } \\
\text { Rate=1/1.1056 }\end{array}$ & $\begin{array}{c}\text { P.V of FCFE(in } \\
\text { Thousands) }\end{array}$ \\
\hline 2016 & $9,96,833.97$ & 0.904 & $9,01,137.91$ \\
\hline & & 0.818 & $8,79,896.63$ \\
\hline 2017 & $10,75,668.26$ & 0.739 & $8,57,784.74$ \\
\hline 2018 & $11,60,737.13$ & 0.669 & $8,37,945.01$ \\
\hline 2019 & $12,52,533.65$ & 0.669 & $3,41,65,974.15$ \\
\hline $2019(\mathrm{TV})$ & $5,10,70,215.48$ & & $\mathbf{3 7 , 6 4 , 2 7 , 3 8 , 4 4 4 . 4 6}$ \\
\hline
\end{tabular}

- Number of outstanding shares are 170160000

Equity Value Per share $=$ Total Equity Value /Shares Outstanding

$$
=37,64,27,38,444.46 / 170160000=221.24
$$

The company is currently trading at 108.43 and calculated intrinsic value is 221.24 .Hence, the selected stock is undervalued. It indicates the investors to buy at the current period.

\section{RESULTS AND DISCUSSION:}

Step 1: Free cash flow to equity is calculated by considering net income, capital expenditure, depreciation, debt ratio and change in non-cash working capital. By referring to calculation, there is more free cash to equity to be observed in 2016 and less in the year 2019. To conclude, the sample period four years figures are been put in the window of average, amounting to $923,777.34$.

Step 2: Calculation of growth rate using retention ratio and return on equity is arrived at $7.91 \%$ showing consistency in the mode of floatation of dividend.

Step 3: In this step, researcher calculate cost of equity with the components such as risk free rate, market risk premium and beta. It is crucial to observe that the beta is assumed to 1.5 for the selected sample period. To summarize, average cost of equity arrived at $10.56 \%$. 
Step 4: In final step, terminal value has been calculated and forecasted equity cash flows for the three years (2020 to 2023). The calculated intrinsic value is 221.24 and market price of Skyworks Solutions, Inc. is 108.43 before the pandemic and now it is trading at 161.39. Since the calculated value is more than the current market price, it's undervalued. It gives strong signal to the investor to buy the selected stock.

\section{CONCLUSION:}

In the current paper, the purpose was to calculate the fundamental or the intrinsic value of the selected equity. EFCF Model has been employed, average of the closing prices of the concerned company's share price. Furthermore, the calculated intrinsic value is compared with the corresponding market value. In the valuation of stock, researcher considered on the free cash flow to equity(FCFE) instead free cash flow of the firm(FCFF). The resulted figure depicts the undervauation of Skyworks Solutions, Inc. which clearly states the strong signal to the investor to go for long position.

\section{REFERENCES:}

1. Damodaran .A(2013), "Strategic Corporate Finance", pp 774-775.

2. Ms.Shradhanjali Panda (2013) "Valuation of Selected Indian Stocks Using Discounted Cash Flow Technique" International Journal of Business and Management Invention ISSN (Online): 2319 - 8028, ISSN (Print): 2319 - 801X www.ijbmi.org Volume 2 Issue 7, PP.09-17. (Chapter 24, pp-750).

3. Christoph Hukelmann, Cesario Mateus \& Irina Mateus (2012) "How Good are Equity Valuation Models in Predicting Stock Prices” SSRN Electronic Journal January 2012 https://www.researchgate.net/publication/276255863.

4. 1 Parakkal Nirmal Kumar, 2 Vishal Mohan \& 3 Alwin Paul Jose (2018) "Validity of Discounted Cash Flow Valuation" Research Review International Journal of Multidisciplinary, Volume-03 ISSN: 2455-3085 (Online) Issue-12, ISSN: 2455-3085 (Online).

5. Ivanovska, Nadica, Zoran Ivanovski, and Zoran Narasanov. 2014. Fundamental Analysis and Discounted Free Cash Flow Valuation of Stocks at Macedonian Stock Exchange. UTMS Journal of Economics 5 (1): 11-24. 